\title{
REVIEW BOARDS \\ IN THE ADMINISTRATIVE PROCESS
}

\author{
JaMEs O. FReEDMan $\dagger$
}

Recent criticism of the federal administrative agencies has called attention to two fundamental problems that threaten and often compromise the effectiveness of the administrative process: delay in the disposition of contested proceedings and failure to achieve coherent policy formulation. There are differences of opinion as to the causes of these problems and differences in estimate about what measures would be most likely to solve them. But there is widespread agreement that the problems exist.

The late James M. Landis, in his Report on Regulatory Agencies to the President-Elect, submitted to John F. Kennedy in December, 1960, put the first problem directly: "Inordinate delay characterizes the disposition of adjudicatory proceedings before substantially all of our regulatory agencies." 1 The statistics he reported from the larger regulatory agencies demonstrated that long periods of time were required by most to bring formal proceedings to a conclusion. ${ }^{2}$ Several agencies required as long as three years to dispose of a proceeding. Other agencies had such large backlogs of pending cases that their present staffs could not hope to clear them up in less than a decade, even assuming that no new cases were docketed in the interim. The available statistics, Dean Landis concluded, "all corroborate the fact of interminable delay." 3 There is some evidence that delay in the

† Associate Professor of Law, University of Pennsylvania. A.B. 1957, Harvard University. LL.B. 1962, Yale University. This article is based upon a report that I prepared as consultant to the Committee on Agency Organization and Procedure of the Administrative Conference of the United States. The Conference has not evaluated or approved this article; the responsibility for its contents is solely mine. I am indebted to Max D. Paglin, Executive Director of the Federal Communications Commission, and Donald J. Berkemeyer, Chairman of the FCC Review Board, for their generous cooperation and counsel.

Arthur M. Best of the Class of 1969 gave me the benefit of his imaginative and painstaking assistance.

$1 \mathrm{~J}$. M. Landis, Report on Regulatory Agenctes to the President-Elect 5 (submitted by the Chairman of the Subcommittee on Administrative Practice and Procedure to the Senate Committee on the Judiciary), 86th Cong., $2 d$ Sess. (Comm. Print 1960) [hereinafter cited as LANDIS REPORT].

2 LANDIS REPORT 5-6.

3 LANDIS REPoRT 6 . On the problem of delay, see also Goldman, Administrative Delay and Judicial Relief, 66 MrcH. L. Rev. 1423 (1968) ; Freedman, The Uses and Limits of Remand in Administrative Law: Staleness of the Record, 115 U. PA. I. Rev. 145 (1966) ; Gellhorn, Administrative Procedure Reform: Hardy Perennial, 48 A.B.A.J. 243 (1962); Note, Judicial Acceleration of the Administrative Process: The Right to Relief From Unduly Protracted Proceedings, 72 YALE L.J. 574 (1963). 
administrative process, at least in some agencies, has become worse since Dean Landis wrote. ${ }^{4}$

Related to the problem of delay is the fact that the cost of pursuing administrative remedies has become steeper. Delay often means increased costs in litigating a protracted proceeding at the administrative level and increased indirect costs while awaiting the ultimate administrative determination. The rise in costs has been particularly acute in cases involving petitions for important certificates or licenses from regulatory agencies. "The result," as Dean Landis said, "is that in many situations the small businessman is practically excluded from an opportunity to compete." 5

The second problem-the failure of the federal administrative agencies to achieve the formulation of coherent policy-has been given its fullest statement by Judge Friendly. ${ }^{6}$ The problem, in his words, "is the failure to develop standards sufficiently definite to permit decisions to be fairly predictable and the reasons for them to be understood." 7 Although most statutes command the agencies they create to develop broad policies in the areas subject to their jurisdiction, such policy formulation as has resulted has widely been regarded as inadequate. $^{8}$ Newton Minow, writing to the President upon completion of his service as Chairman of the Federal Communications Commission, noted that although "[p]olicy making is the critical responsibility of the agency . . . . it is precisely in this area that the agencies have been markedly deficient." 9 Dean Landis came to similarly critical conclusions. ${ }^{10}$

4 See Staff of the Senate Compa. on the Judiciary, 89th Cong., 2d Sess., Evaluation Charts on Delay in Administrative Proceedings (Comm. Print 1966) ; Statement of Frank W. McCulloch, Chairman of the National Labor Relations Board, in Hearings on Review of the National Labor Relations Act Before the Special Subcommittee on Labor of the House Comm. on Education and Labor, 89th Cong., 2d Sess. 31, 32-34 (1966). Cf. Pillsbury Co. v. FTC, 354 F.2d 952 (5th Cir.), complaint dismissed on remand, Trade Cas. $\llbracket 17,484$, at 22,759 (1966).

5 LANDIS REPORT 10. He goes on to note that many companies, able to pass such costs on to consumers in the form of rate increases, lack any real incentive to press for administrative reform. Id.

o H. Friendly, The Federal Adainistrative Agencies: The Need for Better Definition of Standards (1962).

7 Id. at 5-6.

8 See N. Minow, Equal Time: The Private Broadcaster and the Public Interest 277-304 (1964); Hector, Problems of the CAB and the Independent Regulatory Commissions, 69 Y ALE L.J. 931 (1960) ; Long, Proposed Changes in Administrative Law, 19 Sw. L.J. 203 (1965) ; Long, The Proposed New Administrative Procedure Act, 55 GEo. L.J. 761 (1967); Loevinger, Book Review, 68 CoLUM. L. REv. 371, 374-79 (1968).

9 Suggestions for Improvement of the Administrative Process: Letter to President Kennedy from Nezeton $N$. Minow, Chairman, Federal Commnnications Commission, 15 AD. L. Rev. 146, 147 (1963) (emphasis in original) [hereinafter cited as Minow" [etter]. For comments in the specific context of the FCC, see Farragut Television Corp., 8 F.C.C. 2d 279, 285-86 (1967) (statement of Commissioner Johnson); Schwartz, Comparative Television and the Chancellor's Foot, 47 GEo. L.J. 655 (1959); Jaffe, The Scandal in TV Licensing, HARPER's MaGAzINE, Sept. 1957, at 77.

10 LANDIS REPORT 22-24. 
The causes of these problems are complex and varied, differing from agency to agency. Typically, however, delay in the disposition of adjudicatory proceedings is related at least to the growing, insistent press of business before regulatory agencies, lack of adequate agency budgets and staff, ${ }^{11}$ and the substantive and procedural complexity of proceedings--especially comparative hearings-involving multiple parties and issues. Lack of adequate policy formulation is typically related at least to "the inability of the members of multimember commissions to reconcile differences among themselves and the press of adjudicatory business demanding fairly prompt solution." 12 When there are frequent changes in an agency's membership, this problem is aggravated. ${ }^{\mathbf{1 3}}$ Dean Landis described two additional factors stemming from the burdensome demands made upon members of most administrative agencies: the fact that "in adjudicatory matters, the drafting of opinions is delegated [by the members of the agency] to opinion writing sections or assistants so that the rationalization upon which a purportedly informed decision rests is not truly their own"; ${ }^{14}$ and the fact that "briefs of counsel, findings of hearing examiners, relevant portions of the basic records, are rarely read by the individuals theoretically responsible for the ultimate decision." 15 One result, as Chairman Minow stated, "is to not formulate the policy-and to postpone the policy decision to resolution on a case-by-case basis which all too often means inconsistent decisions with the public and the regulated industry not knowing the ground rules. More important, its consequence is that vital planning and policy measures are not undertaken." 16

It would be simplistic to suggest any single proposal as a certain corrective for problems that have often seemed intractable. ${ }^{17}$ But it would be imprudent to ignore procedures that some agencies have found

11 See LANDIS REPORT 6-7.

12 Note, Intermediate Appellate Review Boards for Administrative Agencies, 81 HARV. L. REv. 1325, 1326 (1968) (footnote omitted).

13 See Welborn, Presidents, Regulatory Commissioners, and Regulatory Policy, 15 J. Pub. Law 3 (1966).

14 LANDIS REPort 19-20. See also Great Lakes Airlines, Inc. v. CAB, 291 F.2d 354, 370 (9th Cir.), cert. denied, 368 U.S. 890 (1961). Hector, Govermment by Anonymity: Who Writes Our Regulatory Opinions?, 45 A.B.A.J. 1260 (1959); Westwood, The Davis Treatise: Meaning to the Practitioner, 43 MrNn. L. REv. 607, 615-18 (1959).

15 LANDIS REPORT 20. Some scholars have cited the failure of Congress to assure agencies a mandate to resolve policy issues as another factor related to inadequate policy formulation. See L. JAFFe, Judicial Control of Administrative Action 50 (1965).

16 Minow Letter 147 (emphasis in original). See also M. Bernstein, REgULating Business by INDEPENDENT CoMmission 176-79 (1955).

17 See, e.g., W. Cary, Politics and the Regulatory Agenctes 125-39 (1967); L. Jafre, Judicial Control of Administrative Actron 11-27, 49-51 (1965) ; Jaffe, The Effective Limits of the Administrative Process: $A$ Reevaluation, $67 \mathrm{HARv}$. L. Rev. 1105 (1954). 
workable and effective in ameliorating these problems. One such procedure is the intermediate appellate Review Board. ${ }^{18}$ The Federal Communications Commission and the Interstate Commerce Commission, pursuant to specific statutory authorization, have created Review Boards to hear appeals from decisions of hearing examiners in adjudicatory cases. This article centers upon the experience of the FCC Review Board. ${ }^{19}$ The experience suggests that Review Boards have the capacity for assisting administrative agencies in meeting some of the problems outlined above.

\section{THE FCC REviEW BOARD}

\section{Structure}

In 1961, Congress amended section 5(d) of the Federal Communications Act to authorize the Federal Communications Commission to create an intermediate appellate Review Board:

(1) When necessary to the proper functioning of the Commission and the prompt and orderly conduct of its business, the Commission may, by published rule or by order, delegate any of its functions [with certain listed exceptions] to a panel of commissioners, an individual commissioner, an employee board, or an individual employee, including functions with respect to hearing, determining, ordering, certifying, reporting, or otherwise acting as to any work, business, or matter; except that in delegating review functions to employees in cases of adjudication (as defined in the Administrative Procedure Act), the delegation in any such case may be made only to an employee board consisting of three or

18 The use of such boards was recommended by Dean Landis to President-Elect Kennedy. LANDIS REPORT 85 (Recommendation No. 5).

19 The ICC Review Board was created pursuant to 75 Stat. 517 (1961), 49 U.S.C. $\$ 17$ (1964). Its work is discussed in Note, Intermediate Appellate Review Boards for Administrative Agencies, 81 HARv. L. REv. 1325, 1329-30 (1968). See also ABA Committee on Agency Adjudication, Progress and Problems in Agency Adjudications, 14 AD. L. REv. 239, 245-48 (1962) ; Auerbach, Scope of Authority of Federal Administrative Agencies to Delegate Decision Making Authority to Hearing Examiners, 48 MrNN. L. REv. 823, 845-48 (1964) ; Hutchinson, Improving Commission Organization and Procedure-Some New Developments, 32 ICC PRAC. J. 134 (1964) ; Kahn, Reorganization of the I.C.C.-1961, 29 ICC PrAC. J. 586 (1962); Authority Delegated to Finance Review Board by I.C.C., 29 ICC PRAC. J. 608 (1962).

Three other agencies, the Civil Aeronautics Board, the Federal Trade Commission, and the Federal Maritime Commission, have the authority, pursuant to Reorganization Plans, to delegate review functions to an employee board. Reorganization Plan No. 3 of 1961, 75 Stat. 837 (1961), 49 U.S.C. \$1324 (1964) [CAB]; Reorganization Plan No. 4 of 1961, 75 Stat. 837 (1961), 15 U.S.C. $\$ 41$ (1964) [FTC]; Reorganization Plan No. 7 of 1961, 75 Stat. 840 , 46 U.S.C. $\$ 1111$ (1964) [FMC]. None has exercised the authority, although the $C A B$ has created a system of discretionary review procedures. See text accompanying notes 94-96 infra. For a suggestion of the reasons for the failure of the FTC and FMC to act, see. Auerbach, Scope of Authority of Federal Administrative Agencies to Delegate Decision Making to Hearing Examiners, 48 Mrnv. L. Rev. 823, 833-34 (1964). See also Note, The Progress of Federal Agency Reorganization Under the Kennedy Administration, 48 VA. L. REV. 300 (1962). 
more employees referred to in paragraph (8) of this subsection. Any such rule or order may be adopted, amended. or rescinded only by a vote of a majority of the members of the Commission then holding office. ${ }^{20}$

Prior to this amendment, the Commission had been required by law to review all initial decisions of hearing examiners to which exceptions had been filed, and to hear oral argument upon request. This was obviously a time-consuming responsibility. The amendment granted the Commission discretion to adopt intermediate appellate review procedures if it believed they might help expedite the disposition of adjudicatory cases; these procedures were intended to enable members of the Commission to devote more of their time to policy and planning and to the more significant adjudicatory cases, primarily those involving issues of general communications policy importance. ${ }^{21}$ The Commission took advantage of the amendment and in June, 1962, adopted detailed regulations establishing a Review Board. $^{22}$ Four senior staff employees were appointed to the Board; in 1964 its membership was increased to five, its present strength.

The Review Board began functioning on August 1, 1962. Under regulations issued by the Commission, it is authorized to act in three general areas. (1) The Review Board hears appeals from initial decisions of hearing examiners in all adjudicatory proceedings (including mixed adjudicative and rule-making proceedings), except for those proceedings involving the renewal or revocation of a station license in broadcast and Common Carrier Radio Services; ${ }^{23}$ although section 5(d) would not prevent the Commission from granting the Review Board jurisdiction over such cases, the Commission apparently gave Congress informal assurances at the time the amendment was enacted that review of initial decisions in so-called "death sentence" cases would remain directly in the Commission. ${ }^{24}$ (2) The Review Board passes upon interlocutory appeals from rulings of hearing examiners; these include evidentiary rulings and rulings upon petitions for allowance of amendments to applications, petitions for extensions of

2047 U.S.C. \& 155 (d) (1) (1964).

21 H.R. REP. No. 723, 87th Cong., 1st Sess. 1 (1961); S. REP. No. 576, 87th Cong., 1st Sess. 5 (1961). See Nathanson, Looking Backward 2000-1963: A Personal Viewe of the Administrative Conference, 1961-62, 16 AD. L. REv. 33 (1963).

2247 C.F.R. $\$ \$ 0.361-0.365 ; 1.101-1.117$ (1968).

2347 C.F.R. $\S 0.365$ (a) (1968).

24 The creation of this exception to the Review Board's jurisdiction cannot be justified on principle. The task of review in these cases is not distinguishable from that involved in cases presently entrusted to the Review Board. The "life-or-death" interests concerned would better be served not by removing these cases from the jurisdiction of the Review Board, but rather by providing for their mandatory review by the Commission after Review Board consideration. 
time, and petitions to reopen the record. ${ }^{25}$ (3) The Review Board exercises original jurisdiction over two classes of interlocutory matters: petitions to amend, modify, enlarge, or delete issues upon which the case was designated for hearing by the Commission, ${ }^{26}$ and joint requests filed by broadcast applicants for the approval of agreements looking toward the removal of a conflict between their applications. ${ }^{27}$

Although the Review Board, in reviewing initial decisions of hearing examiners, is "authorized to perform all of the review functions which would otherwise have been performed by the Commission," ${ }^{28}$ it does not have responsibility for the formulation of general communications policy. It is required to decide all matters coming before it on the basis of precedent and existing policy. ${ }^{29}$ The Commission has reserved to itself the authority, in cases raising novel or important issues of law or policy, to review initial decisions directly. ${ }^{30}$

Any person aggrieved by a decision of the Review Board may file an application for review with the Commission. ${ }^{31}$ The Commission's regulations require that an application for review

specify with particularity, from among the following, the factor(s) which warrant Commission consideration of the questions presented:

(i) The action taken pursuant to delegated authority is in conflict with statute, regulation, case precedent, or established Commission policy.

(ii) The action involves a question of law or policy which has not previously been resolved by the Commission.

(iii) The action involves application of a precedent or policy which should be overturned or revised.

(iv) An erroneous finding as to an important or material question of fact.

(v) Prejudicial procedural error. ${ }^{32}$

2547 C.F.R. $\$ 0.365$ (c) (1968).

26 See Fidelity Radio, Inc., 1 F.C.C. 2d 661 (1965); Atlantic Broadcasting Co., 5 F.C.C. $2 d 717$ (1966).

2747 C.F.R. $\$ 0.365$ (b) (1968) ; see "What the Bible Says" Inc., 12 F.C.C. $2 d 610$ (1968); Bay Broadcasting Co., 10 F.C.C. $2 d 331$ (1967); Tinker, Inc., 4 F.C.C. 2d 372 (1966).

2847 C.F.R. \$ 0.361 (d) (1968).

2047 C.F.R. $\$ 0.361$ (d) (1968). See also FCC, Review Board Progress Report, APRIL 1965, at 2 .

3047 C.F.R. $\$ 0.361$ (a) \& (b) (1968). Two recent cases in which the Commission exercised this authority are Midwest Television, Inc., 13 F.C.C. $2 d 478$ (1968) (expansion of CATV service into areas served by regular broadcasting), and Use of the Carterfone Device in Message Toll Telephone Service, 13 F.C.C. 2d 420 (1968) (propriety of telephone company tariff prohibitions against interconnections of customer-provided devices).

3147 U.S.C. $\$ 155$ (d) (4) (1964); 47 C.F.R. $\$ 1.115$ (a) (1968).

3247 C.F.R. $\$ 1.115$ (b) (2) (1968). 
The Commission may grant the application for review in whole or in part, or may deny the application, without specifying reasons for the action taken. ${ }^{33}$ If the Commission denies the application, the decision of the Review Board becomes the decision of the Commission, ${ }^{34}$ which, if it is in other respects a final order, may then be made subject to judicial review. ${ }^{35}$

\section{Performance}

The Commission is plainly impressed with the utility of the Review Board. In a progress report prepared in April, 1965, the Commission appraised the Review Board's performance during the first twenty-nine months of its existence and concluded that it "has well served the purposes for which it was established, and substantial benefits to the Commission and to parties to Commission proceedings have accrued from its operations." 36 This judgment has more recently been affirmed by several members of the Commission. ${ }^{37}$

The Commission believes that two substantial benefits have resulted from the creation of the Review Board: improvement of the hearing process and saving of agency members' time. ${ }^{38}$ They are worth considering separately.

First, establishment of the Board has benefited the hearing processes. The members of the Board have been able to devote greater personal attention to cases, and to dispose of them more expeditiously, than would have been possible for the Commission with its many other responsibilities. The Board has handled a large number of difficult matters with great competence, as indicated by the small number of appeals from its decisions and by the small number of decisions reversed, revised, or remanded by the Commission. Applications for review of Board actions have been handled expeditiously, and no difficulty has been experienced by the Commission in maintaining control over matters of policy. ${ }^{39}$

3347 U.S.C. $\$ 155$ (d) (5) (1964) ; 47 C.F.R. $\$ 1.115$ (g) (1968).

3447 U.S.C. \$155(d) (3) (1964).

3547 U.S.C. $\$ 155$ (d) (7) (1964).

36 FCC, Review BoArd Progress Report, Aprm 1965, at 5. See also Comments of the FCC, in Hearings on S. 1160, S. 1336, S. 1758 and S. 1879 Before the Subcomm. on Administrative Practice and Procedure of the Senate Comm. on the Judiciary', 89th Cong., 1st Sess. 454 (1965).

37 Comments of Chairman E. William Henry and Commissioners James J. Wadsworth and Kenneth A. Cox, in StafF of the Subcomm. on Administrative Practice and Procedure of the Senate Comm. on the Judictary, 89th Cong., 2d Sess., Questionnatre Survey on Delay in Administrative Proceedings 35-40 (Comm. Print 1966).

38 FCC, Review Board Progress Report, April 1965, at 5-6.

3947 U.S.C. $\$ 155$ (d) (5) (1964); 47 C.F.R. $\$ 1.115$ (g) (1968). 
This statement, of course, groups several factors. First, the Review Board has been able to devote far more time and attention to the reviewing function than members of the Commission had been able to do in the past or could do now. Because of the limited definition of their function, members of the Review Board, as the Commission soundly concluded, "can participate much more actively and extensively in discharging their review functions than can members of the Commission." 40 The consequence is that the members of the Review Board are prepared for the oral argument in every case; they have read the pleadings and the briefs and are informed as to the facts and issues involved. Oral argument thus becomes a meaningful dialogue between advocate and decision-maker; in this respect the Board's practice resembles that of a conscientious appellate court. It is understandable that lawyers regard oral argument before the Review Board as more valuable than it is before the Commission.

Second, the Review Board's decisions ${ }^{41}$ have been of high quality. This quality is the result in part of the fact that responsibility for the preparation of every opinion is assigned to an individual member of the Board, under whose name the opinion will appear. ${ }^{42}$ Occasionally the Review Board member responsible for the preparation of an opinion will draft it himself; more frequently, he will supervise the preparation of a draft opinion by a member of the Review Board's staff. Drafts are then circulated among the other members of the Review Board. The Commission has observed, "This desirable merger of the opinion-writing and decision-making processes is feasible in this degree because members of the Board, with their responsibilities limited to adjudicatory hearing cases, can devote themselves for appreciable periods to the preparation of individual opinions." 43

Although the opinion-writing process retains some characteristics of the "institutional decision," 44 the members of the Review Board participate more intensively and effectively in the preparation of the written decision than do the members of most agencies. One result is that decisions of the Review Board typically meet rather than avoid complex issues and support their conclusions with reasoning and relevant authority. ${ }^{45}$ Changes of position are not "slipped into an

40 FCC, Review Board Progress Report, Aprif 1965, at 5.

41 The decisions of the Review Board are published in the Federal Communications Commission Reports.

42 FCC, Review Board Progress Report, Aprit 1965, at 5.

$43 I d$.

44 See $2 \mathrm{~K}$. Davis, Adarinistratrve Law Treatise, ch. 11 (1958).

45 See, e.g., Northeast Broadcasting, Inc. v. FCC, 400 F.2d 749, 758 (D.C. Cir. 1968) ("The Review Board's Decision was detailed, comprehensive and expansive in its discussion of the evidence and the relative weight it attached thereto, and concise and precise as to its ruling and the reasons therefor.") 
opinion in such a way that only careful readers would ever know what had happened, without articulation of reasons, and with the prior authorities not overruled," ${ }^{46}$ as Judge Friendly complained of a series of FCC opinions. Among lawyers who regularly appear before the Commission, there seems to be general agreement that decisions of the Review Board are more predictable than were decisions of the Commission in similar matters before establishment of the Board. They reach results that are significantly more consistent with precedent and existing policy and that adhere more closely to the record facts.

These achievements stem in part from the limits on the Review Board's power. The Board lacks the authority to enter new policy areas. This means that it has no occasion to discuss policy problems with industry representatives. The resulting isolation and anonymity is a salutary protection against hints or charges of improper influence. The Board also lacks the authority to give play or weight to its own expertise in assessing, for example, the comparative qualifications of competing applicants for a broadcast license. This means, as one lawyer has said, that the Review Board will almost always hold for the applicant whose case is best supported in the record in light of the factors that prior Commission decisions have made relevant; conversely, the Review Board is quite unlikely to rely upon the extrarecord intimations that lawyers are accustomed to see play a dispositive role at the Commission level.

It should be said, however, that decisions of the Review Board reflect some of the defects of their virtues. Review Board decisions sometimes tend to be scholastic in their reliance upon precedent, formalistic in their insistence upon compliance with procedural and evidentiary rules, and colorless in their treatment of policy issues. ${ }^{47}$ Given the Review Board's precise mandate and its position in the Commission's decisional structure, it would be surprising if such tendencies did not appear.

One measure of the Commission's high regard for the quality of Review Board decisions may be seen in its reviewing practices. The Commission has not often granted petitions to review decisions of the Review Board and has even less frequently reversed or remanded Review Board decisions.

During the period from August 1, 1962, to December 31, 1967, the Review Board decided 175 appeals from initial decisions. Petitions for review were filed with the Commission in 86 cases. The Commis-

46 H. Friendly, The Federai Administrative Agencies: The Need for Betrer Definition of Standards 63 (1962).

47 Cf. Fitzgerald, Trends in Federal Administrative Procedure, 19 Sw. L.J. 239, 264 (1965); Atlantic Broadcasting Co., 5 F.C.C. $2 d$ 717, 718 (1966). 
sion agreed to review only 13 per cent of the Review Board's decisions : it granted 23 petitions, denied 61, and did not pass on 2 that were withdrawn. Broken down by year, the figures more graphically indicate how infrequently the Commission has agreed to hear appeals from Review Board decisions. During fiscal 1963, the Commission granted no petitions for review; during fiscal 1964, it granted 2 petitions; during fiscal 1965, it granted 6 petitions; during fiscal 1966, it granted 9 petitions; during fiscal 1967, it granted 4 petitions; and during the first half of fiscal 1968, it granted 2 petitions. Of the 23 cases that the Commission agreed to hear during this period, the decision of the Review Board was affirmed in 9 cases, reversed in 9 cases, and remanded in 4 cases; one case had not been decided by the end of the period. ${ }^{48}$

The Commission's use of the power of review has thus been sparing, particularly since review is to be expected in a certain number of cases that are of general communications importance, raise new issues of policy, or make a persuasive claim for changing an existing statement of policy. ${ }^{49}$ Sparing use by the Commission of the power of review is crucial to the Review Board's prestige and effectiveness. The capacity of a Review Board to reduce the average length of time that an agency requires to dispose of proceedings depends in part, as the next few paragraphs suggest, upon how frequently the members of the agency elect to review decisions of the Review Board. And this depends in largest part-the argument has come full circle-upon the quality of Review Board decisions.

In the Commission's language, the Review Board has been able "to dispose of [cases] more expeditiously, than would have been possible for the Commission with its many other responsibilities." 50 Statistical tables supplied by the Commission appear to support this contention. $^{51}$ During fiscal 1961, before the Review Board had been created, the Commission required an average time of 262 days from the date on which the initial decision was issued to dispose of an appeal from an initial decision of a hearing examiner. By comparison, the Review Board, during the first 29 months of its existence, required an average time of 172 days to dispose of the same appeal-an average saving of almost three months per proceeding. The statistics with

48 These statistics and the ones that follow are based upon information supplied by Donald J. Berkemeyer, Chairman of the Review Board. Statistics may also be found in FCC, REVIEW BOARD Progress REPORT, ApRI 1965.

49 Some such cases, of course, will be reviewed directly by the Commission. See note 30 supra and accompanying text.

50 FCC, Review BoArd Progress Report, April 1965, at 5. day.

51 Id., Tables No. 1, 2, and 3. The figures that follow are rounded to the nearest 
respect to interlocutory actions are of similar proportions. During fiscal 1961, the Commission required an average time of 66 days to dispose of an interlocutory matter. The Review Board, during its first 29 months, required an average time of 36 days, thus saving about one month per case.

The statistics with respect to the Review Board's experience for the years subsequent to 1964 are of a similar order. During fiscal 1965, the average length of time required to dispose of an appeal from an initial decision was 228 days; during fiscal 1966, it was 267 days; during fiscal 1967, it was 244 days; and during fiscal 1968, it was 210 days. The statistics for these years with respect to the disposition of interlocutory matters indicate average time periods of 40 days per case during fiscal 1965; 43 days during fiscal 1966; 38 days during fiscal 1967; and 43 days during the first half of fiscal 1968.

As these statistics reveal, the average time the Review Board has required to dispose of matters before it has fluctuated in recent years. These fluctuations have coincided with an enlargement of the jurisdiction of the Review Board and a want of sufficient staff assistance.

It is important to note that the statistics do not take account of the time consumed when a party petitions the Commission to review the decision of the Review Board. If such a petition is filed, ${ }^{52}$ the saving in days is reduced by the time required by the Commission to act on the application. If the Commission denies the petition, time may be saved over the average pre-Review Board experience, not least because the Federal Communications Act allows the Commission to deny such petitions "without specifying any reasons therefor." 53 However, if the Commission grants the petition and reviews the decision of the Review Board on the merits, the total amount of time required for action by the Review Board and the Commission will almost certainly be greater than the time that would have been required if the initial decision had been reviewed directly by the Commission. ${ }^{54}$

In 1966, Chairman E. William Henry said that the Review Board "has been able to decide such cases [of adjudication] more expeditiously than was previously the case when a Commission decision was required." 55 Although the Review Board in recent years has found itself

52 It must be filed within 30 days of the decision. 47 C.F.R. $\$ 1.115$ (d) (1968).

5347 U.S.C. $\$ 155$ (d) (5) (1964).

54 FCC, Review Board Progress Report, AprIL 1965, Table No. 3, n.1. More thorough consideration of the issues, however, may be a countervailing benefit.

55 Comments of Chairman E. William Henry, in Staff of tere Subcomm. on Administrative Practice and Procedure of the Senate Comm. on the Judiciary, 89th Cong., 2D Sess., Questionnaire Survey on Delay in Administrative ProCEEDINGS 35, 36 (Comm. Print 1966). 
taking increasing amounts of time to decide matters before it, such figures cannot of course fairly be compared with the Commission's 1961 statistics. No one can know how long today's Commission, with new responsibilities in the areas of CATV and satellite communications, would require, in the absence of a Review Board, to decide adjudicatory appeals.

In addition to improving the agency's hearing processes, the Commission regards creation of the Review Board as having resulted in a second substantial benefit:

[B]y virtue of delegations made to the Board in hearing proceedings, the Commission has been enabled to devote a significantly larger portion of its time and energies to major matters of policy and planning and to cases of adjudication involving issues of general communications importance. We cannot stress the importance of this benefit too strongly. There is an ever-increasing number of complex and vital policy matters coming before the Commission because of the changing nature of the communications field (e.g., CATV, space satellite, network television procurement and production). These matters call for close study by the Commission and frequent meetings of Commissioners where there can be the necessary exchange of views and evolvement of policy. The Review Board, by taking over the routine hearing cases, has contributed significantly to the Commission's ability to devote more time and effort to these important policy issues. ${ }^{56}$

Statistics appended to the Commission's progress report give some suggestion of the amount of time that creation of the Review Board has freed for members of the agency to devote to duties other than adjudication. During the 29-month period (March 1, 1960 to July 31,1962 ) immediately preceding creation of the Review Board, the Commission devoted a total of 45 days or partial days, representing 130 hours, to hearing oral argument. By comparison, during the 29-month period immediately following creation of the Review Board (August 1, 1962 to December 31, 1964), the Commission devoted only 29 days or partial days, representing 81 hours, to hearing oral argument. $^{57}$

These figures understate the savings in Commission time that resulted from creation of the Review Board. They do not reflect the concomitant savings in time that a reduction in adjudicatory appellate responsibilities produces in preparing for oral argument, deliberating, and drafting final opinions. Furthermore, these figures include cases 
within the Review Board's jurisdiction that were designated for hearing before the Review Board was established and, under a "grandfather clause," retained on the Commission's docket, as well as television cases, which were not placed within the Review Board's jurisdiction until June $15,1964 . .^{58}$

It has become clear in recent years that what the Commission calls the "second substantial benefit"-freeing agency members from the demands of many adjudicatory appeals - ought to be regarded as the Review Board's most significant contribution.

The experience of the Federal Communications Commission suggests that creation of an intermediate appellate Review Board can bring significant benefits to the regulatory process. A Review Board can apply agency policy with more consistency and more detailed attention to the record than can the agency members themselves. A Review Board can reduce the average time required by the agency to dispose of a proceeding. Most important, a Review Board can free the time of agency members to consider matters of policy and planning by disposing of an absolute number of adjudications that the members of the agency need not decide. These benefits are, as the Commission properly characterized them, substantial.

\section{Definition of a Review Board's Role}

\section{Trwo Models of Review Boards}

The performance of the FCC Review Board has been shaped by its structure, jurisdiction, and authority. Before deciding to create an intermediate appellate Review Board, an agency must make some preliminary judgments about the function the Board is to perform. Unless judgments about form and function are thoughtfully reached, the establishment of a Review Board may only add another stage of administrative proceedings, achieving no countervailing gain. The agency's goal must be to identify and describe a differentiated function for the Board, and to give it a mandate that will enable it to perform that function well.

This section of the article will explore some of the considerations relevant to the decision to create a Review Board. In undertaking this exploration, it will be useful to make reference to two models of a Review Board-the "judicial model" and the "administrative model." The terms lack precision; they do not correspond to an absolute reality. But they provide a convenient framework for describing two different conceptions of the function that a Review Board might serve. The 
models do not of course exhaust the possible conceptions of a Review Board; nor should they be regarded as describing even polar conceptions, for they do not. The models are intended only to suggest that value judgments concerning the appropriate functions of a Review Board are closely related to the details of the Board's structure, jurisdiction, and authority.

The judicial model conceives the function of a Review Board as primarily deciding appeals from initial decisions of hearing examiners in adjudicative cases as nearly as possible on the basis of precedent and formal statements of agency policy. The Board is expected to apply existing law rather than to make new policy, although of necessity it "may consider the extension of present policies to include new factual situations." 59 When policy issues of first impression arise, the Board is expected to certify them to the members of the agency for decision. The judicial model posits the Board's function in deciding questions of law as analogous to that of a lower court subject to review by an appellate tribunal.

The administrative model conceives the function of a Review Board as blending at least some of the roles-deciding appeals in adjudicative cases as well as formulating policy-that members of the agency perform. The Board is expected to speak the agency's mind, not merely to rephrase prior statements; to decide issues as it believes the agency would decide them, whether or not precedent reaches that far. The Board is expected to contribute through its work to the formulation, rather than the mere application, of agency policy. Because its job is to serve almost as an alter ego of the agency, a Review Board based on the administrative model would have a wider jurisdiction and greater substantive authority than one based on the judicial model.

\section{Jurisdiction}

In creating a Review Board, one of the most important concerns that an agency must confront is the appropriate definition of the Review Board's jurisdiction. The Federal Communications Act authorized the Commission to create a Review Board to perform "any of its functions . . . including functions with respect to hearing, determining, ordering, certifying, reporting, or otherwise acting as to any work, business, or matter." Bo The Commission elected to create a Review Board based upon the judicial model. It granted the Review Board authority to act in three general areas: review of initial decisions of hearing examiners in all adjudicative matters, including mixed ad-

80 Charles County Broadcasting Co., 25 P \& F Ramio REg. 903, 907 (1963).

6047 U.S.C. \& 155 (d) (1) (1964). 
judicative and rulemaking proceedings; interlocutory appeals from rulings of hearing examiners; and original jurisdiction in two important areas of interlocutory matters. The decisions that the Federal Communications Commission made in defining the jurisdiction of its Review Board may usefully be examined.

In amending the Federal Communications Act to authorize the creation of a Review Board, Congress did not attempt to describe the jurisdiction of the Review Board. Instead, it gave the Commission complete freedom to determine which of its functions should be delegated to the Review Board. This freedom has allowed the Commission to adjust the Review Board's jurisdiction in light of the Board's performance and of changing exigencies within the Commission. Thus, in 1964 the Commission enlarged the Review Board's authority to review additional categories of initial decisions. ${ }^{61}$ It was the Commission's freedom to make these changes on its own motion that made them possible at all. Had Congress defined the Review Board's jurisdiction, redefinition would have required an amendment to the statute; it is plain that the legislative process could not fashion such redefinitions with either the sensitivity or the celerity of an agency.

If a Review Board is to make a significant contribution toward expediting agency decisions and freeing agency members' time, the agency must be prepared to grant it a subject matter jurisdiction that accounts for a large number of cases and to allow most of its decisions to become final. The success of the FCC Review Board, as the discussion above indicates, ${ }^{62}$ supports this principle.

Equally crucial to the success of a Review Board will be the capacity of the members of the agency to identify the classes of cases appropriate for intermediate appellate review procedures. If the members of the agency fail in this task, creation of a Review Board will only add to delay. What principles are relevant to making this determination? One commentator has written:

[M] any of the very complex cases such as route cases in the $\mathrm{CAB}$ or large merger cases before the ICC depend on the relevance and interrelation of a very large number of "economic facts" such as the effect of the merger or new route, or the validity of a complicated cost study.

. . The agency, in evaluating the appropriateness of a new route, for example, is really performing the managerial function of resource allocation; the ultimate decision involves a judgment concerning the relationship among an open-ended series of variables, and the final determination in the particular 
case cannot be deduced from a generally applicable rule. Policy formulation in the legislative sense is not possible; a system of intermediate appellate review cannot reduce delay in the disposition of cases without compelling the agency to formulate artificial guidelines for the allocation of industry resources. $^{63}$

The jurisdiction that the Federal Communications Commission gave to its Review Board is appropriate for a Review Board based on the judicial model because it is limited to cases involving policy application rather than policy formulation. An agency whose docket includes a high percentage of cases involving policy formulation might benefit only from a Review Board based upon the administrative model; such a Review Board would require jurisdiction over quasilegislative or rulemaking proceedings.

\section{Review of the Review Board}

The amendment to the Federal Communications Act that authorized creation of a Review Board also provides for review of its decisions. Any person aggrieved may apply to the Commission for review; the Commission may also review Board decisions on its own motion. Absent such review, a decision or order of the Board becomes that of the Commission. Application for review is a condition precedent to judicial review of the Commission's action. ${ }^{64}$

63 Note, Intermediate Appellate Review Boards for Administrative Agencies, 81 HARv. L. REv. 1325, 1331 (1968) (footnote omitted).

6447 U.S.C. $\$ 155$ (d) provides in part:

(3) Any order, decision, report, or action made or taken pursuant to any such delegation, unless reviewed as provided in paragraph (4) of this subsection, shall have the same force and effect, and shall be made, evidenced, and enforced in the same manner, as orders, decisions, reports, or other actions of the Commission.

(4) Any person aggrieved by any such order, decision, report or action may file an application for review by the Commission within such time and in such manner as the Commission shall prescribe, and every such application shall be passed upon by the Commission. The Commission, on its own initiative, may review in whole or in part, at such time and in such manner as it shall determine, any order, decision, report, or action made or taken pursuant to any delegation under paragraph (1) of this subsection.

(5) In passing upon applications for review, the Commission may grant, in whole or in part, or deny such applications without specifying any reasons therefor. No such application for review shall rely on questions of fact or law upon which the panel of commissioners, individual commissioner, employee board, or individual employee has been afforded no opportunity to pass.

(6) If the Commission grants the application for review, it may affirm, modify, or set aside the order, decision, report, or action, or it may order a rehearing upon such order, decision, report, or action in accordance with section 405 of this title.

(7) The filing of an application for review under this subsection shall be a condition precedent to judicial review of any order, decision, report, or action made or taken pursuant to a delegation under paragraph (1) of this subsection. 
The most notable aspect of these provisions is the freedom and responsibility left the Commission to design a system to review decisions of the Review Board. By providing that a decision of the Review Board shall become the decision of the Commission absent such review, the statute grants the Commission the freedom to make final any Review Board decisions it chooses. By providing that review of Review Board decisions shall be "in such manner as the Commission shall prescribe," the statute grants the Commission the responsibility of selecting wise principles of review. ${ }^{65}$

An examination of the principles selected by the Commission is instructive. Under the Commission's regulations, any person aggrieved by a decision of the Review Board may file an application requesting review by the Commission:

(b) (2) The application for review shall specify with particularity, from among the following, the factor(s) which warrant Commission consideration of the questions presented:

(i) The action taken pursuant to delegated authority is in conflict with statute, regulation, case precedent, or established Commission policy.

(ii) The action involves a question of law or policy which has not previously been resolved by the Commission.

(iii) The action involves application of a precedent or policy which should be overturned or revised.

(iv) An erroneous finding as to an important or material question of fact.

(v) Prejudicial procedural error.

(c) No application for review will be granted if it relies on questions of fact or law upon which the designated authority has been afforded no opportunity to pass. ${ }^{86}$

A note to the Commission's regulations advises persons seeking review by the Commission that "the application for review should be

65 Lawyers who regularly practice before an agency may be concerned that creation of a Review Board will reduce their access to members of the agency. So long as a petition for review may be filed with the members of the agency, the substance of this concern is that creation of a Review Board will reduce a lawyer's opportunity to argue important issues of administrative policy to the presidential appointees who are finally responsible for the formulation of agency policy. This concern can be greatly tempered, however, by wise agency action in granting and denying review of decisions below. Indeed, agencies are likely to be as sensitive as their practitioners to the existence of policy issues that require responsible consideration at the very top; members of agencies are not likely, by design or inadvertance, to forfeit their authority to decide these issues. An agency can also temper this concern by following the procedure that the FCC followed in establishing its Review Board of soliciting comments on its proposed regulations before making them final. See Fitzgerald, Trends in Federal Administrative Procedure, 19 Sw. L.J. 239, 262 (1965).

8647 C.F.R. § 1.115 (1968). 
prepared with the understanding that its purpose is not to obtain a Commission decision on the merits of the issues but rather to convince the Commission to review those issues." ${ }^{67}$

The regulations make plain that the Commission has the authority on its own motion to order the record of a proceeding before it for review; ${ }^{68}$ it is not dependent upon the motion of a person aggrieved. Once an application for review has been filed with the Commission, it "may grant the application for review in whole or in part, or may deny the application, without specifying reasons for the action taken." 63 If the Commission grants the application for review, "it may order such further procedure, including briefs and oral argument, as it may deem useful" 70 and may affirm, reverse, modify, or set aside the Review Board's action, or may remand the proceeding for reconsideration. ${ }^{71}$

These regulations give the Commission complete control over selection of cases for review. They do not require the Commission to grant an application for review in any case; this means the Commission can realize the time-freeing potential of the Review Board to the extent it chooses. The regulations do not prohibit the Commission from granting an application for review in any case and they allow the Commission to bring up cases for review on its own motion; this means the Commission has authority to place its imprint on the aggregate work product of the Review Board.

Review of decisions of the Review Board is thus totally at the option of the Commission. There is much to be said for this arrangement. First, the Commission cannot be committed by Review Board action to a position that the members of the agency do not share. The Commission's regulations take full account of Professor Davis' view that "the policy judgment should be an easy one that no one but the Presidential appointees can have final responsibility for what is done in the name of an agency. The agency heads should have power to delegate, but they should lack power to delegate in such a way as to deprive themselves of their residual power." 72

Second, the Commission cannot be bound by findings of fact with which it disagrees, even if the hearing examiner and the Review Board have concurred in finding them. The Commission retains, in the

6747 C.F.R. $\S 1.115$ (1968).

6s 47 C.F.R. $\$ 1.117$ (a) (1968).

6947 C.F.R. $\$ 1.115(\mathrm{~g})$ (1968).

7047 C.F.R. $\$ 1.115(\mathrm{~h})$ (1968).

7147 C.F.R. $\$ 1.115$ (i) (1968).

72 Statement of Kenneth C. Davis, in Hearings on S. 1663 Before the Subconnm. on Administrative Practice and Procedure of the Senate Comm. on the Judiciary, 88th Cong., 2d Sess. 256 (1964). 
language of the Administrative Procedure Act, "all the powers which it would have in making the initial decision." 73 Retention by the Commission of plenary power to resolve issues of material fact is preferable to any limitation by such formulations as "unless clearly erroneous" or "unless contrary to the weight of the evidence." Chairman McCulloch of the National Labor Relations Board has pointed out that "in many cases questions of law, policy, and fact are intermingled." 74 Wise resolution of questions of law and policy may be thwarted if an agency lacks the authority to disagree with the Review Board's evaluation of intermingled questions of fact.

Third, the Commission cannot be precluded from reviewing a case merely because the grounds upon which review is sought do not meet the suggested criteria for granting an application for review. The Commission might, for example, choose to review a proceeding because the proposed agency action involves severe consequences for a party. There is a symbolic value in such review-attention by presidential appointees to individual instances of special hardship-which makes its retention important. A system that limited review by agency members to specified grounds or specified issues could deny recognition to this value.

\section{Problems in Establishing a Review Board}

\section{Appointment}

A Review Board will be valuable only if an agency is prepared to make first-rate appointments to the Board. There can be no compromise with this principle if the Review Board is to win respect or acceptance from hearing examiners, the agency's staff, and the practicing bar. If the Review Board fails to win both respect and acceptance, pressures to abolish it will gather.

The success of the FCC Review Board rests in part on the fact that the original appointees (all of whom still serve) are persons of undoubted ability and extensive experience. All five had achieved high positions within the agency before being named to the Review Board. ${ }^{75}$ They brought varied experience to their joint work; they were, in the 1968).

73 Administrative Procedure Act $\S 8,80$ Stat. 387, 5 U.S.C. $\S 557$ (b) (Supp. III,

74 Statement of Frank W. McCulloch, Chairman of the National Labor Relations Board, in Hearings on $S .518$ Before the Subcomm. on Administrative Practice and Procedure of the Senate Comm. on the Judiciary, 90th Cong, 1st Sess. 223 (1967).

75 Two had served as Chief of the Office of Opinions and Review, one had been Chief of the Renewal and Transfer Division of the Broadcast Bureau, one had been Assistant General Counsel in charge of the Regulatory Division, and one had been an Engineering Assistant to a Commissioner. 
statutory language, "qualified by reason of their training, experience, and competence, to perform such review functions." 78

The FCC's decision to name senior staff employees to the Review Board undoubtedly thinned the ranks at a very important level. But the price had to be paid; it gave an earnest of the agency's commitment to making the Review Board work. Adherence to this commitment will not exact as great a price in the future; once the members of the original Board have been named, vacancies can be expected to occur one at a time.

Four further comments about the selection of Review Board members may be worth making. First, an agency may think it desirable on occasion to select a hearing examiner to serve on its Review Board. Some of the arguments supporting the occasional selection of a hearing examiner are similar to those supporting the occasional selection of a trial judge to serve on an appellate court. Persons experienced in the discipline of finding facts bring a useful and particularized expertise to the review function. The possibility of promotion is valuable both in attracting able men to the corps of hearing examiners and in sustaining their morale after they undertake service. And finally, hearing examiners will more tolerantly accept reversals of their decisions when at least one of the Review Board members has first-hand knowledge of the conditions under which examiners work.

Second, the members of an agency may think it desirable on occasion to select a non-lawyer, such as an engineer or a rate expert, to serve on its Review Board. The selection of a non-lawyer may be particularly appropriate when sophisticated technical expertise is necessary for resolution of cases within the Review Board's jurisdiction. Although technical experts could be assigned to the Review Board's staff, an agency might well conclude that Board members are more likely to listen to a technical expert if he is a colleague and peer rather than a staff subordinate. The decision of the FCC Review Board, composed of four lawyers and an engineer, to sit in ten randomly-selected panels of three means that some panels consist of three lawyers while others consist of two lawyers and an engineer. Lawyers who regularly practice before the FCC do not seem to regard the difference as significant. This suggests that there should not be an $a$ priori bar to the selection of a non-lawyer to serve on a Review Board even if it is constructed on the judicial model.

Third, an agency ought not regard itself as limited to selecting only senior staff employees to serve on its Review Board. The test

7647 U.S.C. $\S 155$ (d) (8) (1964). 
of selection must be suitability to perform the Review Board's functions. Some senior staff employees ably suited for their present responsibilities may not have the particular qualities that service on the Review Board will require; more junior employees may possess these qualities. Conversely, an agency may think it desirable to have a Commissioner serve on the Review Board, particularly if its functions approximate those of the administrative model. It should be noted, however, that the presence of a Commissioner-whose party affiliation would be a matter of public record--would prevent the Review Board on which he served from having the bipartisan character that Congress has typically required for actions by presidential appointees; ${ }^{\mathbf{7 7}}$ in addition, the presence of a Commissioner might inhibit his Review Board colleagues from disagreeing with him and deter his colleagues on the agency from reversing Review Board decisions in which he participated.

Fourth, an agency's commitment to the theory of a Review Board will be tested when a vacancy occurs, perhaps several years after the Board has been created, perhaps when several new members sit on the agency. It is imperative that an agency, in filling the vacancy, not succumb to the false assumption that the Review Board has become an institution able to perform its function and retain its authority without regard to the quality of the appointment made. An agency that uses Review Board vacancies to solve problems presented by staff employees who have not worked out well in their present positions will substantially weaken the Review Board.

\section{Status and Tenure}

The GS status of Review Board members is directly related to the quality of persons who will accept service on the Review Board and to the Review Board's ability to command respect within the agency and without. Unless staff members and the practicing bar regard appointment to the Review Board as a promotion to a very senior position in the Civil Service hierarchy, the prestige and authority of the Review Board will suffer.

The Federal Communications Act requires that Review Board members "be in a grade classification or salary level commensurate with their important duties, and in no event less than the grade classification or salary level of the employee or employees whose actions are to be reviewed." 78 Hearing examiners at the FCC, as in most other places in the federal government, hold GS-16 positions. All five members

77 See, e.g., Federal Communications Act $\$ 154$ (b), 47 U.S.C. $\$ 154$ (b) (1964); Federal Trade Commission Act $\$ 1,15$ U.S.C. $\$ 41$ (1964).

7847 U.S.C. $\S 155$ (d) (8) (1964). 
of the Review Board hold GS-17 grade classifications. Although the statutory requirement is met as long as members of the Review Board hold GS-16 grade classifications, the elevation in grade classification is obviously desirable.

By comparison, the Interstate Commerce Act does not place grade classification requirements on appointments to ICC Review Boards. None of the fifteen members of the agency's five Review Boards holds a GS-17 position, and only four chairmen hold GS-16 positions; the fifth chairman and the remaining ten members hold GS-15 positions. It is not surprising that the ICC has had great difficulty in persuading GS-16 hearing examiners to take GS-15 or GS-16 Review Board positions, particularly in view of the greater tenure protections that examiners enjoy under the Administrative Procedure Act. ${ }^{\text {i9 }}$ This problem is more easily described than remedied, since most agencies will have only a limited number of super-grades (GS-16 through -18) available.

Related to the question of status is that of tenure. In creating a Review Board, an agency will have to decide on the term of office of its members. Several alternatives are possible.

An agency might believe that Review Board members should hold office indefinitely and be removable only for cause. This arrangement would be similar to that enjoyed by hearing examiners. Such a judgment would be consistent with creation of a Review Board based upon a judicial model. Such an essentially tenured status-assuming that an agency could grant it in the absence of specific statutory authority-would preserve the independence of Review Board members and protect them against the fear (whether real or imagined) of reprisal for decisions they have rendered. It would also, no doubt, be an attractive factor in persuading able staff employees to accept appointment to a Review Board.

The five members of the FCC Review Board have no formal protection against removal, although an $\mathrm{FCC}$ regulation provides that they shall "serve indefinitely"; ${ }^{80}$ they are as vulnerable as other staff employees to being shifted to other positions within the agency. It seems clear, however, that institutional norms and expectations have developed that would exert strong moral pressure against removal of a member of the Review Board for anything less than substantial reasons. This may suggest that Review Board members performing

79 Section 11 of the Administrative Procedure Act provides that a hearing examiner "may be removed by the agency in which he is employed only for good cause established and determined by the Civil Service Commission on the record after opportunity for hearing." 80 Stat. 528, 5 U.S.C. $\$ 7521$ (Supp. III, 1968).

8047 C.F.R. $\$ 0.361$ (e) (1968). 
essentially judicial functions can achieve significant de facto protection against removal without good cause, even if formal provision granting such protection is not or cannot be made.

The fact that members of the FCC Review Board have GS-17 status also serves as a deterrent to removal. They could not be shifted to other positions within the agency without being required to accept a lower grade classification; an agency is likely to hesitate before exacting such a sacrifice. Granting a GS-17 status to Review Board members may provide a protection against removal which is similar to that enjoyed by hearing examiners, without severely restricting an agency's power to make changes in Review Board membership in unusual situations.

An agency, of course, might believe that Review Board members should be removable more readily than a "for good cause" rule would allow. This arrangement would be consistent with the creation of a Review Board designed to approximate the administrative model. It would allow the agency to change the membership of the Review Board to reflect changes in the membership and philosophy of the agency itself. An agency might adopt such an arrangement if it believed that a Review Board could fulfill its purposes best when its members were sympathetic with and responsive to the views of present agency members. However, an agency's authority to bypass the Review Board and directly review hearing examiners' decisions may minimize the necessity of making Review Board members readily removable in order to promptly implement changes in agency policy.

Other arrangements are also possible. Review Board members might, for example, be appointed for a fixed term of years; provision could be made for reappointment. An agency that adopted such an arrangement could achieve certain gains in flexibility and in the renewal of energy that a system of rotation offers. An arrangement that contemplated rotating terms of service might make it easier professionally for a Review Board member to remain at the agency in another position when his term expired.

\section{Insulation From Ex Parte Contacts}

The degree to which Review Board members should be insulated from contact with members of the agency or members of the staff will depend largely upon the function that the Review Board is expected to perform. The more nearly the Review Board is based upon the judicial model, the more appropriate it may seem to insulate its members from discussions of cases pending before it. 
The FCC Review Board is insulated by several statutory provisions and regulations. Section 409 (c)(1) of the Federal Communications Act provides:

In any case of adjudication (as defined in the Administrative Procedure Act) which has been designated by the rommission for a hearing, no person who has participated in the presentation or preparation for presentation of such case at the hearing or upon review shall (except to the extent required for the disposition of ex parte matters as authorized by law) directly or indirectly make any additional presentation respecting such case to the hearing officer or officers or to the Commission, or to any authority within the Commission to whom, in such case, review functions have been delegated by the Commission under section 155(d) (1) of this title, unless upon notice and opportunity for all parties to participate. $^{81}$

This section represents a congressional judgment that interested persons and agency staff members who have participated in the preparation or presentation of a case should not have any additional and ex parte contact with the authority that will decide the case, whether it be the Review Board or the members of the agency. In addition, section 155(d) (8) directs that Review Board members

shall not be responsible to or subject to the supervision or direction of any officer, employee, or agent engaged in the performance of investigative or prosecuting functions for any agency. ${ }^{82}$

These two statutory provisions are reinforced by an FCC regulation:

Neither the Commission nor any of its members will discuss the merits of any matter pending before the Board with the Board or any of its members. .3

In practice, these provisions mean that members of the FCC Review Board do not discuss the merits of specific cases pending before them with anyone in the agency. One reason the Review Board has been given its own staff of lawyers, opinion writers, and technical experts is to make unnecessary any consultation between Review Board members and agency employees who also serve the members of the agency.

The manner in which the insulation of the FCC Review Board has been achieved is consistent with the judicial model. A Review 
Board based on the administrative model might function differently. An agency creating such a Review Board might think it desirable to permit consultation on some occasions between members of the Review Board and members of the agency and its staff. Although it may be assumed that members of the Review Board would not discuss pending adjudicatory proceedings with members of the agency or with the staff, such consultation would not be inappropriate when a Review Board has been delegated the task of rulemaking.

Because rulemaking proceedings often involve large issues of policy and have relevance to significant areas of the agency's jurisdiction, an agency might properly believe that Review Board members ought not be insulated from staff members whose experience would be helpful in formulating a sound rule. Full access to the agency's staff might also reduce the likelihood that the agency would reject a Review Board decision based on the months of costly proceedings typical of rulemaking. In addition, a decision by an agency to grant the Review Board a significant role in the formulation of rules may bring Review Board members into an advantageous competition with other agency employees, such as bureau chiefs, who otherwise would make the only recommendations to members of the agency on the lines that new policy should follow.

\section{Response of Hearing Examiners}

The decision to create a Review Board may cause concern among an agency's hearing examiners. Professor Davis, commenting in 1965 on experience at the FCC, said, "Examiners, of course, are opposed to the whole idea of the Review Board, for they prefer the idea of limited review of examiners' initial decisions." ${ }^{84}$ The statement is probably less true today than it was in 1965, largely because hearing examiners have learned that the Review Board's success in the predictable application of standards has increased their opportunities to make decisions that will not be appealed or will stand upon appeal. ${ }^{85}$

Nevertheless, the creation of a Review Board means that examiners' decisions will be reviewed in the first instance by employees of the agency rather than by presidential appointees; examiners may regard this as diminishing their stature in the agency's overall decision-

84 I K. Davis, Administrative Law Treatise $\$ 9.05$ (Supp. 1965). The Federal Trial Examiners Conference opposed the legislation authorizing the FCC and ICC Review Boards. Hearings Before the Subcomm. on Communications of the Senate Comm. on Commerce on Reorganization of FCC, 87th Cong., 1st Sess. 82-83 (1961).

85 Cf. E. Redford, National Regulatory Commissions: Need for a New Look 12-13 (1959). But cf. text accompanying note 87 infra. 
making process. ${ }^{86}$ Sometimes it may mean, as it does at the ICC, that decisions of GS-16 examiners will be reviewed by GS-15 members of Review Boards. Sometimes it may mean, as it does at the FCC, that examiners' decisions will be reviewed by a Review Board whose membership does not include anyone with experience as a hearing examiner. The members of the Review Board may give the impression that they do not have complete respect for the competence of hearing examiners; one hearing examiner at the FCC reported to a Senate subcommittee that the members of the Review Board "regard the initial decision as a point of departure. To them it is pretty much just another pleading." 87 Under these circumstances hearing examiners may see the creation of a Review Board as a threat to their status and prestige; the result may be a lowering of morale.

These are human concerns-perhaps they are inevitable-and to some degree they can be met by sensible administration. They may be accompanied, however, by a deeper concern impossible to accommodate: the concern, plainly justified by the example of the FCC Review Board, that a Review Board is more likely to give intensive scrutiny to the record than members of the agency typically do, and is more likely to notice procedural lapses, insufficiencies of proof, and examiners' errors. This, of course, is one of the functions of a Review Board.

\section{The Desirability of Enabling Legislation}

The success of the FCC Review Board raises the question of the desirability of legislation that would extend the concept of intermediate appellate review procedures to other agencies. Proposals calling for such an extension to most of the federal administrative agencies have been made in three recent sessions of Congress. ${ }^{88}$ Few agencies have been opposed to permissive legislation that would enable agencies in

${ }^{86}$ See Auerbach, Scope of Authority of Federal Administrative Agencies to Delegate Decision Making to Hearing Examiners, 48 MINN. L. REv. 823, 866 (1964).

87 Comments of Thomas A. Donahue, in Staff of the Subcoms. on Administrative Practice and Procedure of the Senate Comiar. on the Judiciary, 89th Cong., 2d Sess., QuestionnaIre Survey on Deiay in Administrative Proceedings 235 (Comm. Print 1966).

88 S. 1663, 88th Cong., 1st Sess. (1963) ; S. 1336, 89th Cong., 1st Sess. (1965) ; S. 518, 90th Cong., 1st Sess. (1967). S. 1336 passed the Senate but failed in the House. The most recent proposal, S. 518, provided:

Except to the extent that the establishment of an agency appeal board is clearly unwarranted by the number of proceedings in which exceptions are filed or that agency appellate procedures have been otherwise provided by Congress: (A) Each agency shall establish by rule one or more agency appeal boards composed of agency members, hearing examiners (other than the presiding officer), or both.

S. 518, 90th Cong., 1st Sess. \$8(c) (2) (1967). See Byse, The Judicial Review Provisions of S. 518, The Proposed Administrative Procedure Act of 1967, 20 AD. L. Rev. 198 (1968). 
their discretion to establish a Review Board. Almost every agency has objected, however, to blanket legislation that would compel agencies to establish a Review Board; this has been true even when the proposed legislation has provided some statutory exceptions for circumstances in which use of a Review Board might be unnecessary or inappropriate. ${ }^{89}$

Extensive testimony offered at congressional hearings over a period of years has made clear that legislation compelling all agencies to create Review Boards would be unwise. The basic reason, subject to illustration by many examples, is that such legislation would place the differentiated procedures of agencies with disparate functions "in a straitjacket"; ${ }^{90}$ it might not allow an agency the flexibility, for example, of creating a Review Board for certain classes of cases only, or for certain separable parts of cases. Or it might require review procedures of agencies that have no need of them.

Some agencies may have manageable workloads that do not disable their members from giving adequate attention to their adjudicatory and policy-making duties. Chairman White of the Federal Power Commission told a Senate subcommittee in 1967, "The Commission does not have many appeal proceedings. Thus, 29 examiners' decisions were rendered in 1966 and exceptions were taken or review instituted on the Commission's own motion in 25 cases. In my judgment, 25 contested gas and electric cases a year do not justify the appeal board procedure, considering the substantial expenditures of money and people that an appeal board would require." 91 When the members of an agency are called upon to decide a relatively small volume of adjudicatory cases, creation of a Review Board may be unnecessary either to expedite the disposition of adjudicatory proceedings or to free the time of agency members for policy-making tasks.

Most agencies, of course, have a greater number of appeals than Chairman White describes for the Federal Power Commission. However, they may have devised procedures to make their workloads manageable. The Securities and Exchange Commission, for example, has the power to control the number of cases on its adjudicatory docket; its docket of contested hearings is limited to cases that it elects to initiate. This is a power denied to agencies such as the Federal Communications Commission that must respond to applications and petitions filed by private parties. By carefully limiting the number of cases that it brings, by sometimes chastising informally rather than

89 Note, Intermediate Appellate Review Boards for Administrative Agencies, 81 HARV. L. REV. 1325, 1333 (1968).

$90 \mathrm{Id}$.

91 Comments of Chairman Lee C. White, in Hearings on S. 518 Before the Subcomm. on Administrative Practice and Procedure of the Senate Comm. on the Judiciary, 90th Cong., 1st Sess. 189 (1967). 
proceeding to an administrative hearing, by inviting offers of settlement, by entering into consent agreements, the Securities and Exchange Commission is able to exercise a significant measure of control over its workload and thereby increase its regulatory efficiency. However, "the fact that a particular agency may be keeping abreast of its work does not always indicate that it is making the wisest use of the time and skills of its members and staff." 92 It may indicate instead that the agency has artificially limited the size of its docket so that its workload, although manageable, does not include enough cases to allow it to effectuate the regulatory aims of the statute entrusted to its administration. ${ }^{93}$ Therefore, the fact that an agency has succeeded in limiting its workload to a manageable size will not always be inconsistent with the possibility that intermediate appellate review procedures are desirable.

Other agencies may seek to make their workloads more manageable by adopting discretionary review procedures at the agency level. The Civil Aeronautics Board adopted such procedures in 1963 pursuant to authority granted by Reorganization Plan No. 3 of $1961 ;^{94}$ several other agencies possess similar authority but have not exercised it. $^{95}$ Discretionary review procedures allow the members of an agency to limit their plenary consideration to cases that raise issues of the greatest importance. ${ }^{96}$ An agency should adopt such procedures only if it has sufficient confidence in the work of its hearing examiners to allow a significant percentage of initial decisions to stand unreviewed. An agency which believes that its hearing examiners merit such confidence also might charge them with considerably more power over the conduct of the hearing than they may now possess and might limit time-consuming interlocutory appeals. Because "almost 30 percent of all the hearing examiners in federal service (161 out of 578) may retire from service during the next three years as a result of mandatory or optional retirement," ${ }^{97}$ agencies will have a significant opportunity

92 Committee on Internal Organization and Procedure, Delegation of Final Decisional Authority, in Selected Reports of the Administrative Conference of the United States, S. Doc. No. 24, 88th Cong., 1st Sess. 157, 158-59 (1963).

${ }_{93}$ See Phillips Petroleum Co., 24 F.P.C. 537, 546 (1960), aff'd, 303 F.2d 380 (D.C. Cir. 1961), affirmed sub nom. Wisconsin v. FPC, 373 U.S. 294 (1963).

94 Reorganization Plan No. 3 of 1961, 75 Stat. 837 (1961), 49 U.S.C. $\$ 1324$ (1964); CAB Delegation of Function to Hearing Examiners, 14 C.F.R. $\$ 301.47$ (1963).

95 See Reorganization Plan No. 4 of 1961, 75 Stat. 837 (1961), 15 U.S.C. § 41 (1964) [Federal Trade Commission]; Reorganization Plan No. 7 of 1961, 75 Stat. \$40, 46 U.S.C. \$1111 (1964) [Federal Maritime Commission]; cf. E. Gellhorn, The Treatment of Confidential Information by the Federal Trade Commission, 36 U. CHI. L. REv. 113, 181-83 (1968).

${ }^{30}$ See Auerbach, Scope of Authority of Federal Administrative Agencies to Delegate Decision Making to Hearing Examiners, 48 MrNN. L. Rev. 823, 853-69 (1964).

${ }_{07}$ Miller, The Vice of Selective Certification in the Appointment of Hearing $E_{x-}$ aminers, 20 AD. L. REv. 477, 485 (1968). 
to strengthen the quality of the hearing examiner corps. In these circumstances, an agency that has the authority to adopt discretionary review procedures may conclude that such procedures are at least as likely to free the time of agency members as would an intermediate appellate review system.

Still other agencies whose workloads might seem to suggest the desirability of Review Board procedures may regard the adjudicatory burden as a necessary or useful one to bear in order to secure advantages that might be compromised under a Review Board system. This may be particularly true of agencies concerned with prompt disposition of certain classes of cases. Chairman McCulloch of the National Labor Relations Board expressed concern to a congressional subcommittee in 1967 that mandatory imposition of a Review Board, by adding a level of internal review, "would unduly burden and delay the handling of election cases and nullify the Congressional intention to expedite the processing of such cases." 98

A similar conclusion could be reached by agencies whose members believe that constant exposure to actual records and the shifting factual patterns that litigation reveals, although it may be time-consuming and repetitive, serves an educational function. A succession of mine-run cases may hold hints of the emergence of new problems the significance of which the agency's staff may not be as likely to recognize. The nembers of the agency may therefore regard such exposure as essential to the proper performance of their policy-making duties.

One might argue with many of these agency estimates. Some may understate the need for a Review Board; others may overstate the advantages of present arrangements. Agencies are as prone as other institutions to make the error, in de Tocqueville's precise phrase, of confusing the familiar with the necessary. Even if the estimates are arguable, however, their variety demonstrates that mandatory imposition of Review Board procedures on every agency would be an indiscriminate reform. " $[N]$ o formula of reform can be applied across the board to all agencies," ${ }^{00}$ and it would be a serious mistake to enact legislation that seeks to require the creation of Review Boards wholesale, as it were, rather than retail. Legislation that lacks the support and sympathy of agencies, particularly if it seeks to control internal procedures, is not likely to succeed in any event.

This does not mean that it would be inappropriate for Congress to enact enabling legislation authorizing federal administrative agencies

98 Comments of Chairman Frank W. McCulloch, in Hearings on S. 518 Before the Subcomm. on Administrative Practice and Procedure of the Senate Conm. on the Judiciary, 90th Cong., ist Sess. 223 (1967).

99 Bernstein, Book Review, 81 Harv. L. REv. 1886, 1887 (1968). 
to exercise their discretion to create Review Boards. To the contrary, such legislation would place the power of decision where it belongs. By allowing agencies to consider the establishment of Review Boards without the necessity of having to persuade Congress to grant the statutory authority to do so-indeed, by mooting the question whether statutory authority is necessary-such legislation might stimulate experimentation with appellate review procedures.

By enacting enabling legislation only, Congress runs the risk that it will not be implemented; the risk will extend to agencies where the desirability of Review Board procedures may seem the most clear. But the risk of inertia or bad judgment by some agencies seems preferable to the serious possibility that unworkable, uncongenial procedures will be fastened on agencies that perhaps do not need or want them. It is wholly proper, if Congress believes it desirable, to require agencies to report from time to time whether they have elected to create a Review Board, and the reasons for their decisions. ${ }^{100}$ In any event, the risk of non-implementation is one that Congress can eliminate by enacting individualized legislation for any agency about which it is specifically concerned.

In framing enabling legislation, Congress should take care to preserve wide opportunity for agency choice of structure, jurisdiction, and authority of Review Boards. It would be shortsighted to prescribe detailed procedures and requirements for Review Boards on the assumption that agencies that establish Review Boards will do so for the same reasons. Decisions to establish Review Boards will reflect different estimates of different needs in different agencies. Enabling legislation will be useful in the degree that it allows individual agencies the latitude to establish Review Boards that can truly be responsive to their distinctive needs.

\section{APPENDIX}

On December 11, 1968, the Administrative Conference of the United States adopted the following recommendation:

Recommendation No. 6-Delegation of Final Decisional Authority SubJect to Discretronary

REvIEW BY THE AgENCY

1. In order to make more efficient use of the time and energies of agency members and their staffs, to improve the quality of decision without sacrificing procedural fairness, and to help eliminate delay in

100 See Committee on Internal Organization and Procedure, Delegation of Final Decisional Authority, in Selected Reports of the Administrative Conference of the United States, S. Doc. No. 24, 88th Cong., 1st Sess. 157, 163 (1963). 
the administrative process, every agency having a substantial caseload of formal adjudications should consider the establishment of one or more intermediate appellate boards or the adoption of procedures for according administrative finality to presiding officers' decisions, with discretionary authority in the agency to affirm summarily or to review, in whole or in part, the decisions of such boards or officers.

2. Section 8 of the Administrative Procedure Act, 5 U.S.C. 557, should be amended as necessary to clarify the authority of agencies to restructure their decisional processes along either of the following lines:

\section{(a) Intermediate appellate boards}

(1) Whenever an agency deems it appropriate for the efficient and orderly conduct of its business, it may, by rule or order:

(A) establish one or more intermediate appellate boards consisting of agency employees qualified by training, experience, and competence to perform review functions,

(B) authorize these boards to perform functions in connection with the disposition of cases of the same character as those which may be performed by the agency,

(C) prescribe procedures for review of subordinate decisions by such boards or by the agency, and

(D) restrict the scope of inquiry by such boards and by the agency in any review, without impairing the authority of the agency in any case to decide on its own motion any question of procedure, fact, law, policy, or discretion as fully as if it were making the initial decision.

(2) Any order or decision of an intermediate appellate board, unless reviewed by the agency, shall have the same force and effect and shall be made, evidenced, and enforced in the same manner as orders and decisions of the agency.

(3) A party aggrieved by an order of such board may file an application for review by the agency within such time and in such manner as the agency shall prescribe, and every such application shall be passed upon by the agency.

(4) In passing upon such applications for review, an agency may grant, in whole or in part, or deny the application without specifying any reasons therefor. No such application shall rely upon questions of fact or law upon 
which the intermediate appellate board has been afforded no opportunity to pass.

(5) An agency, on its own initiative, may review in whole or in part, at such time and in such manner as it shall determine, any order, decision, report, or other action made or taken by an intermediate appellate board.

(6) If an agency grants an application for review or undertakes review on its own motion, it may affirm, modify, reverse, or set aside the order, decision, report or other action of the intermediate appellate board, or may remand the proceeding for reconsideration.

(7) The filing of an application for agency review shall be a condition precedent to judicial review of any order of an intermediate appellate board.

(8) Agency employees performing review functions shall not be responsible to or subject to the supervision or direction of any employee or agent engaged in the performance of investigative or prosecuting functions for any agency. (b) Discretionary review of decisions of presiding

(1) When a party to a proceeding seeks administrative review of an initial decision rendered by the presiding officer (or other officer authorized by law to make such decision), the agency may accord administrative finality to the initial decision by denying the petition for its review, or by summarily affirming the initial decision, unless the party seeking review makes a reasonable showing that:

(A) a prejudicial procedural error was committed in the conduct of the proceeding, or

(B) the initial decision embodies

(i) a finding or conclusion of material fact which is erroneous or clearly erroneous, as the agency may by rule provide,

(ii) a legal conclusion which is erroneous, or

(iii) an exercise of discretion or decision of law or policy which is important and which the agency should review.

(2) The agency's decision to accord or not to accord administrative finality to an initial decision shall not be subject to judicial review. If the initial decision becomes the decision of the agency, however, because it is summarily affirmed by the agency or because the petition for its review is denied, such decision of the agency will be subject to judicial review in accordance with established law. 